\title{
Globalna sprawiedliwość podatkowa w międzynarodowym prawie podatkowym
}

\section{Wprowadzenie}

W obliczu zjawisk kryzysowych w ekonomii, w sferze socjalnej, kulturze oraz w szczególności stawiając czoło powszechnemu bezrobociu, zastanawiamy się nad poczuciem sprawiedliwości. Dochodzimy do wniosku, że wypracowane znacznie wcześniej modele ekonomiczne i prawne nie zawsze sprawdzają się w czasach współczesnych. Jesteśmy światkami społecznego niezadowolenia występującego w krajach rozwijających się i wysoko rozwiniętych. Obserwujemy duże nierówności wśród mieszkańców w danym kraju oraz porównując tych mieszkańców z obywatelami innych krajów. Dlatego dziś problem sprawiedliwości jest szczególnie aktualny.

Odczucie niesprawiedliwości zasadniczo nasila się w momencie kryzysów, gdy nie widzimy żadnych perspektyw. Zwykle oznacza to, że następuje utrata nadziei na poprawę sytuacji. Faktem jest, że około połowa pracujących populacji świata zarabia mniej niż dwa dolary dziennie. Oznacza to, że bez względu na miejsce położenia ich kraju w świecie, zarabiają zbyt mało, aby wydźwignąć z biedy siebie i swoją rodzinę $e^{1}$ W 20 najbogatszych krajach świata średnie dochody ich mieszkańców są 37 razy większe niż przeciętne dochody w 20 krajach najbiedniejszych. W ostatnich dekadach ta różnica wzrosła o ponad połowę. Większość współczesnych społeczeństw stanowią społeczeństwa klasyczne, w których przejawia się sprawiedliwość hierarchiczna. Każdy poziom pionowej władzy jest

* Dr Edward Juchniewicz - Katedra Prawa Finansowego, Wydział Prawa i Administracji, Uniwersytet Gdański.

1 Odmiennie rozumiemy pojęcie ubóstwa. Granice są zawsze względne. Duży odsetek ludzi mieszkających poniżej granicy ubóstwa w USA posiada klimatyzację i samochód. Zupełnie odmiennie pojmuje się ubóstwo mieszkańców Trzeciego Świata. Definicja ubóstwa: bieda (ubóstwo) - to pojęcie ekonomiczne i socjologiczne opisujące brak dostatecznych środków materialnych dla zaspokojenia potrzeb jednostki, w szczególności w zakresie jedzenia, schronienia, ubrania, transportu oraz podstawowych potrzeb kulturalnych i społecznych, http://pl.wikipedia.org/wiki/Bieda (dostęp: 28.05.2012). 
rządzony zwyczajem ukierunkowanym wolą rządzących oraz znajdujące swoją fundamentalną podstawę w obowiązującym prawie ${ }^{2}$.

W kontekście globalnej sprawiedliwości stawiamy zasadnicze pytanie, czy jakakolwiek polityka suwerennych państw powinna w pierwszej kolejności skupić się na pomocy osobom znajdującym w skrajnym ubóstwie, czy pomagać osobom należącym do współczesnego ruchu oburzonych (niezadowolonych) ${ }^{3}$ ?

Problem sprawiedliwości zawsze był, jest i będzie tematem spornym. Zawiera on zarówno dylematy natury filozoficznej, jak i praktycznej. Jesteśmy świadomi, że niesprawiedliwość może dotyczyć każdego człowieka w różnych sytuacjach życiowych. Sprawiedliwość także stanowi główną zasadę funkcjonowania państw, rynków oraz dobrych relacji międzyludzkich. Może się wydawać, że wiemy, co to jest sprawiedliwość oraz co składa się na jej treść. Szczególna analiza problemu pokazuje jednak, że jest to zadanie skomplikowane. Od dawna próbowano wypracować formułę sprawiedliwości, w tym także opracować uniwersalne i jednolite określenie sprawiedliwości. W obliczu różnych definicji należałoby przyjąć, że sprawiedliwość stanowi ideę właściwą dla okresu istnienia wspólnoty ludzi. Jest ona zasadą szczególnie zmienną i uzależnioną od konkretnych warunków historycznych, tradycji, wartości akceptowanych przez ludzi, przede wszystkim analizujących zasadę sprawiedliwości. Przy istnieniu wielu różnych koncepcji sprawiedliwości możemy twierdzić, że rozważania o sprawiedliwości zawsze będą subiektywne. Sprawiedliwym będzie to, co konkretna osoba będzie uznawać za sprawiedliwe 4 .

Sprawiedliwość według Arystotelesa - równość - uchodzi za rzecz sprawiedliwą i jest nią istotnie, ale nie dla wszystkich, tylko dla równych; także nierówność uchodzi za sprawiedliwą, bo też jest nią rzeczywiście, lecz znów nie dla wszystkich, tylko dla nierównych. Ludzie pomijają przy tym wzgląd na to,

2 Zob. np. How Have the World's Poorest Fared Since the Early 1980s?, Table 3, p. 28; www. wds.worldbank.org/external/default/WDSContentServer/IW3P/IB/2004/07/22/000112742_200407 22172047/Rendered/PDF/wps3341.pdf (dostęp: 28.05.2012).

${ }^{3}$ Ruch Oburzonych to umowne określenie dla międzynarodowej społeczności, kontestującej obecną politykę walki ze światowym kryzysem odbywającą się kosztem społecznym. Jesteśmy $99 \%$ społeczeństwa, które płaci za kryzys wywołany przez 1\%. Zob. www.facebook.com/pages/Ruch-Oburzonych/296273007051245?sk=info (dostęp: 28.05.2012).

${ }^{4} \mathrm{~W}$ zakresie badań naukowych dotyczących sprawiedliwości można wyróżnić wiele nurtów badawczych. W szczególności: sprawiedliwość jako poszukiwania dobra (antyczna tradycja) - przedstawiciele: Platon, Arystoteles, Cyceron i in.; sprawiedliwość jako gwarancja praw i wolności (umowna tradycja czasów współczesnych) - przedstawiciele: T. Hobbes, J. Locke, J.-J. Rousseau, I. Kant i in.; normatywne koncepcje sprawiedliwości jako element współczesnej teorii politycznej - przedstawiciele: R. Nozick, J. Rawls, R. Dworkin, A. MacIntyre, Henri de Saint-Simon, M. Nussbaum i in. Zob. Канарш Г. Ю., Сочиальная справедливость: философские конщепиии и российская ситуация, Москва 2011, с. 12-127; zob. także: L. B. Solum, Natural Justice, „American Journal of Jurisprudence” 2006, vol. 51, s. 65-105; „Illinois Public Law Research Paper” no. 08-28, http://ssrn.com/abstract=959646 (dostęp: 28.05.2012). 
dla kogo coś ma być sprawiedliwe, toteż sądzą fałszywie. Przyczyna leży w tym, że sąd dotyczy ich samych, a niemal wszyscy ludzie w swojej własnej sprawie są złymi sędziami ${ }^{5}$.

Szczególną cechą sprawiedliwości jest jej wieloznaczny charakter - wyróżniamy pragnienie szczęścia, zadowolenia z życia, pewność jutrzejszego dnia, równouprawnienia i jednakowych możliwości, równych dochodów itd. Szeroko rozumowany charakter sprawiedliwości uzasadnia również istnienie różnorodnych koncepcji i teorii sprawiedliwości.

Za punkt odniesienia wszelkich koncepcji sprawiedliwości należałoby uznać szeroko pojmowaną równość i wolność. Różne koncepcje sprawiedliwości w zakresie odpowiednio nakreślonych uwarunkowań zawierają w sobie zróżnicowane określenia równości i wolności. W gospodarce wolnorynkowej w zakresie tematu mamy na uwadze równość jednostek i ich wolność w zakresie kształtowania stosunków gospodarczych. Natomiast błędnym rozumowaniem jest utożsamianie sprawiedliwości jedynie z równością i wolnością, gdyż wszelkie skrajne zmiany tych wartości powodują istotną zmianę w zakresie tychże wartości. Pełna wolność może skutkować nierównością podmiotów, a regulowanie równości prowadzi w istocie do ograniczenia wolności. Mając na uwadze wszelkie uzasadnienia dla nierówności i braku wolności w różnych koncepcjach sprawiedliwości, powinniśmy dążyć do wypracowania rozwiązań mających na celu dobro człowieka ${ }^{6}$.

Obciążając rozumowaną sprawiedliwość różnymi wartościami, pozwalamy także na prezentację tego problemu w świetle różnych relacji społecznych. Na przykład możemy mówić o sprawiedliwości rozwiązań politycznych, ekonomicznych, prawnych ${ }^{7}$, stosunków międzynarodowych itd. ${ }^{8}$ Pryzmat globalny nadaje koncepcji sprawiedliwości inną perspektywę. Procesy globalizacji przedstawiane są na równi z procesami modernizacji. W aspekcie sprawiedliwości nie ujmujemy ich w granicach danego państwa albo wspólnoty, lecz w kategoriach całego współczesnego świata. Z globalnej perspektywy jednostki zasadniczo mówimy o niesprawiedliwości, z uwagi na procesy często niezwiązane z danym państwem, w którym dana jednostka zamieszkuje. Rozmaite polityki krajowe

${ }^{5}$ Arystytoles, Polityka, thum. L. Piotrowicz, [w:] Arystoteles, Dzieła wszystkie, t. I, Warszawa 2003, s. 64.

${ }^{6}$ Zob. L. Kaplow, S. Shavell, Principles of Fairness versus Human Welfare: On the Evaluation of Legal Policy, „Law-Econ Discussion Paper” March 2000, no. 277; http://ssrn.com/abstract=224946 lub http://dx.doi.org/10.2139/ssrn.224946 (dostęp: 28.05.2012).

7 Patrz np. J. Raz, The Argument from Justice, or How Not to Reply to Legal Positivism, [w:] G. Pavlakos (red.), Law, Rights and Discourse: The Legal Philosophy of Robert Alexy, „Oxford Legal Studies Research Paper" 2007, no. 15, s. 17-36; http://ssrn.com/abstract=999873 (dostęp: 28.05.2012).

${ }^{8}$ Patrz. np. J. P. Ruger, Health and Social Justice, „The Lancet” 2004, vol. 364, s. 1075-1080; http://ssrn.com/abstract=950875 (dostęp: 28.05.2012). 
i zagraniczne znacznie oddalonych suwerennych państw, w tym także finansowe, stawiane są jako przejawy niesprawiedliwości wobec jednostek zamieszkałych w tych oddalonych krajach.

Globalne procesy istotnie wpływają na kierunki rozwoju poszczególnych krajów, jak też restrukturyzują społeczne procesy tych krajów. Współczesny termin ,globalizacja” jest pojęciem wieloznacznym i mocno zakorzenionym w leksykonie naukowym ${ }^{9}$. Możemy stwierdzić, że oznaką globalizacji w prawie są dynamicznie zmieniające się normy prawne, stanowiące przejaw globalizacji prawa i wolności człowieka oraz zapoczątkowujące powstawanie globalnych rządów w świecie. Procesy te zmieniają strukturę prawa międzynarodowego. Kierunek globalnych tendencji pozwala mówić o uniwersalizacji, harmonizacji, w znaczeniu regionalnym amerykanizacji i europeizacji prawa ${ }^{10}$. Zmiany dotyczą zarówno prawa prywatnego, jak i publicznego ${ }^{11}$, w tym także prawa podatkowego. Dziś rozróżnienie między prawem krajowym i międzynarodowym staje się mniej istotne. W kontekście globalnych procesów wyróżniamy podstawowe parametry progresu, które zasadniczo zawierają w sobie elementy zasady sprawiedliwości. Możemy do tej kategorii zaliczyć np. wzrost gospodarczy, równość społeczeństw i ich jednostek, prawa człowieka i dobrobyt. Normalnym zjawiskiem jest, że opisywane procesy globalizacji są oceniane zarówno pozytywnie, jak i negatywnie; mają również miejsce skrajne - w jedną i drugą stronę - oceny tych procesów. W kontekście finansów publicznych i prawa finansowego globalizację należy traktować jako postępujący proces, w ramach którego nie został wypracowany w szczególności system jednolitej światowej gospodarki finansowej, polityki fiskalnej i monetarnej oraz społeczeństwa obywatelskiego.

\section{Granice opodatkowania w ujęciu globalnym}

Przejawy niesprawiedliwości należy uznać za podstawową przesłankę tego, że sprawiedliwość podatkowa zasługuje na kolejny etap badań w prawie podatkowym. Współczesnym zjawiskiem, mającym charakter stricte prawnopodatkowy, jest ogólnoświatowa tendencja wprowadzania nowych podatków. W doktrynie

9 Globalizacja - ogół procesów prowadzących do coraz większej współzależności i integracji państw, społeczeństw, gospodarek i kultur, czego efektem jest tworzenie się ,jednego świata”, światowego społeczeństwa; zanikanie kategorii państwa narodowego; kurczenie się przestrzeni społecznej i wzrost tempa interakcji poprzez wykorzystanie technologii informacyjnych oraz wzrost znaczenia organizacji ponad- i międzynarodowych, w szczególności ponadnarodowych korporacji. Zob. więcej: http://pl.wikipedia.org/wiki/Globalizacja (dostęp: 28.05.2012).

10 Patrz: С. В. Поленина, О. А. Гаврилов, Н. П. Колдаева, Е. Г. Лукьянова, Е. В. Скурко, Взаимодействие глобализации на правовую систему России, „Государство и право” 2004, nr 3.

11 Patrz np. J. M. Smits, Law Making in the European Union: On Globalization and Contract Law in Divergent Legal Cultures, „Louisiana Law Review” 2007, vol. 67, no. 4, s. 1181-1203; http://ssrn.com/abstract=1104386 (dostęp: 25.06.2012). 
prawa podatkowego problematyka nowych podatków ma swoją reakcję naukową, w szczególności analizowane polityki podatkowe i podatki podlegają ocenie w zakresie granic prawa podatkowego, opodatkowania i przedmiotu podatków ${ }^{12}$. Globalny charakter tego zjawiska przejawia się w powszechnej praktyce współczesnych ustawodawstw dotyczących kreowania zupełnie nowych instytucji podatkowych, nieznanych teorii i praktyki prawa podatkowego. Dziś pojawianie się nowych podatków możemy uznać za reakcję wobec kryzysów ekonomicznych i finansowych, co skutkuje zmniejszaniem się wpływów budżetowych. W tym znaczeniu systemy podatkowe i podatki stają się podstawowym instrumentem realizacji funkcji fiskalnej i stymulacyjnej finansów publicznych. Zjawisku wprowadzania nowych podatków nadano w literaturze przedmiotu nazwę Armagedonu podatkowego (ang. Taxmagedon) ${ }^{13}$.

Przejawem szerokiego przedmiotu opodatkowania jest wprowadzenie albo dyskusja na temat podatku bankowego oraz podatku od transakcji finansowych (zwanego podatkiem Robin Hooda albo podatkiem Tobina) ${ }^{14}$ - jako instrumentu finansującego deficyty budżetów państwowych i pewnego rodzaju karę finansową dla instytucji finansowych za globalny kryzys finansowy lat 2007-2010. W związku z tym nasuwa się pytanie z dziedziny filozofii prawa finansowego (podatkowego) w kontekście globalnej sprawiedliwości podatkowej i innych zasad prawa podatkowego: czy podatki mogą być nakładane jedynie w celu realizacji funkcji fiskalnej podatków albo czy w dużym stopniu mogą mieć bardziej regulacyjny (stymulacyjny) charakter? Przykład podatku bankowego stanowi w pewnym sensie globalny przejaw realizacji funkcji regulacyjnej podatków ${ }^{15}$. Obok głośnych debat związanych z podatkiem bankowym, w ubiegłych latach można było usłyszeć wiele propozycji nowych podatków lub nowych przedmiotów opodatkowania. W licznych krajach przedmiotem daleko idących dyskusji i prac jest zagadnienie podatku węglowego ${ }^{16}$, podatku od napojów o dużej zawartości

${ }_{12}$ Zob. J. Gliniecka, Granice opodatkowania, [w:] A. Drwiłło, D. Maśniak (red.), Leksykon prawa finansowego. 100 podstawowych pojęć, Warszawa 2009.

${ }_{13}$ Patrz: M. A. Sullivan, Are You Ready for Taxmageddon?, www.taxanalysts.com/www/features.nsf/Articles/F294AFE98B22872A85257A130057A0CA?OpenDocument (dostęp: 25.05.2012).

${ }_{14}$ Zob. np. President Obama Proposes Financial Crisis Responsibility Fee to Recoup Every Last Penny for American Taxpayers, www.whitehouse.gov/the-press-office/president-obama-proposes-financial-crisis-responsibility-fee-recoup-every-last-penn (dostęp: 25.05.2012).

${ }_{15}$ Zob. R. S. Avi-Yonah, Taxation as Regulation: Carbon Tax, Health Care Tax, Bank Tax and Other Regulatory Taxes, „University of Michigan Law \& Economics, Empirical Legal Studies Center Paper” no. 10-020; „University of Michigan Public Law Working Paper” no. 216; http://ssrn. com/abstract=1664045; zob. też: M. Keen, The Taxation and Regulation of Banks, „IMF Working Papers" 2011, s. 1-38; http://ssrn.com/abstract=1923520 (dostęp: 25.06.2012).

16 Zob. R. S. Avi-Yonah, D. M. Uhlmann, Combating Global Climate Change: Why a Carbon Tax is a Better Response to Global Warming than Cap and Trade, „Stanford Environmental Law Journal” 2009, vol. 28, no. 3; „University of Michigan Public Law Working Paper” no. 117; http://ssrn.com/abstract=1333673; zob. też: G. E. Metcalf, D. A. Weisbach, Design of a Carbon Tax, 
cukrów $^{17}$, podatku od singli (bykowego) ${ }^{18}$, podatku od internetowej pornografii, podatku od marihuany, podatku od prostytucji itd. W uzasadnieniu wprowadzania nowych podatków rządy często odwołują się do zasady sprawiedliwości podatkowej. Należałoby przypomnieć, że podatki, które są ściśle związane z zachowaniem konsumentów, w literaturze prawa podatkowego mają już swoje nazwy. Określane są jako podatek od grzechu ${ }^{19}$ oraz podatek Pigou ${ }^{20}$.

Problem nowych podatków i innych instytucji prawnych ma również inny charakter oraz jest ściśle związany z procesami globalizacji i modernizacji. Rządy suwerennych państw, odwołując się do zasady sprawiedliwości, kształtują w wielu krajach nową politykę podatkową dotyczącą opodatkowania transakcji elektronicznych ${ }^{21}$.

Drugim powszechnym zjawiskiem dotyczącym większości krajów na świecie jest zwiększanie obciążeń podatkowych w zakresie podatków konsumpcyjnych, w szczególności podatku od towarów i usług (zwanego podatkiem od wartości dodanej - VAT). Wpływy z tytułu tego podatku stanowią główną część podatkowych dochodów budżetowych wszystkich państw członkowskich Unii Europejskiej oraz także wszystkich innych krajów wysoko rozwiniętych. Stanowi to odpowiedź polityk podatkowych i systemów podatkowych na zwiększającą się mobilność podatników (dotyczy podatków bezpośrednich) oraz znacznie mniejszą

„University of Chicago Law \& Economics, Olin Working Paper” no. 447; „University of Chicago Public Law Working Paper" no. 254; http://ssrn.com/abstract=1324854; zob. też przykłady i dyskusję na temat podatków oraz innych instrumentów ekonomicznych w: W. C. Whitesell, Climate Policy Foundations: Science and Economics with Lessons from Monetary Regulation, Cambridge 2011; M. S. Andersen, P. Ekins (red.), Carbon-Energy Taxation: Lessons from Europe, Oxford 2010.

17 R. Vinelli, Sugar Taxes Aren't Sweet: The Case Against Taxes on Sugar-Based Drinks, 2009; http://ssrn.com/abstract=1410068 (dostęp: 25.06.2012).

${ }^{18}$ Najciekawszą propozycją jest oferta środowisk akademickich Japonii, gdzie uznano, że wysokość obciążeń podatkowych podatkiem bykowym powinna być uzależniona od stopnia piękności panów. Zdaniem Takuro Morinaga sprawiedliwe będzie opodatkowanie najwyższymi stawkami podatkowymi najbardziej pięknych jednostek. Natomiast najbardziej brzydkie osobniki, które z kolei z tego powodu nie mogą znaleźć „drugiej połówki”, powinny uzyskać ulgi podatkowe.

19 Zob. G. Lucas jr, Saving Smokers from Themselves: The Paternalistic Use of Cigarette Taxes, „University of Cincinnati Law Review” 2012, vol. 80; http://ssrn.com/abstract=1942068; I. W. H. Parry, J. A. Miron, Should Alcohol Taxes Be Raised?, „Regulation” 2009, vol. 32, no. 3, s. 10-13; http://ssrn.com/abstract=1484930 (dostęp: 25.05.2012).

${ }^{20}$ Podatek Pigou to teoretyczna forma podatku nakładana w celu zniwelowania negatywnych skutków efektów zewnętrznych. Nazwa podatku pochodzi od nazwiska brytyjskiego ekonomisty, Arthura Pigou, który jako pierwszy rozpatrywał problem efektów zewnętrznych i zaproponował sposób na zniwelowanie ich negatywnych skutków przez nałożenie podatku w odpowiedniej wysokości; http://pl.wikipedia.org/wiki/Podatek_Pigou (dostęp: 25.05.2012); zob. także: B. Bartlett, Taxing Sin: A Win-Win for Everyone?, „Tax Notes” 2010, vol. 128, no. 12, s. 1289; http://ssrn.com/ abstract=1693167 (dostęp: 25.05.2012).

${ }^{21}$ E. Juchniewicz, Taxing virtual world - the legal limit of taxation, [w:] Tax and Budget Law: Modern Problems of Property Relations, Voronezh 2012, s. 170-180. 
mobilność konsumentów. Do kategorii tych krajów nie możemy zaliczyć Stanów Zjednoczonych, gdzie największe wpływy są generowane z podatku dochodowego od osób fizycznych. Dlaczego nie z podatku od towarów i usług? Odpowiedź jest prosta - w systemie podatkowym USA brak podatku VAT ${ }^{22}$. Debata dotycząca wprowadzenia podatku VAT zagościła w wielu amerykańskich ośrodkach akademickich i nie tylko. Zwolennicy wprowadzenia podatku twierdzą, że gdyby udało się wprowadzić ten podatek konsumpcyjny na poziomie obciążeń podatkowych właściwych państwom UE, to USA byłyby w stanie sfinansować całe zadłużenie kraju w okresie około 20 lat. Przeciwnicy podatku odwołują się do zasady sprawiedliwości podatkowej, określając ten podatek jako najmniej sprawiedliwy $\mathrm{w}$ teorii podatków. $\mathrm{W}$ istocie obciążenia podatkowe tym podatkiem nie uwzględniają zdolności płatniczej podatników. Każdy człowiek, bez względu na wysokość jego dochodów, ponosi ten sam ciężar podatku konsumpcyjnego, nabywając ten sam towar w sklepie ${ }^{23}$.

\section{Globalna sprawiedliwość podatkowa}

Nadając zjawisku akcent podatkowy, zasadniczo nie zmieniamy przyjętej w doktrynie prawa natury rozumowania sprawiedliwości podatkowej. Możemy analizować i przedstawiać sprawiedliwość podatkową w kontekście ustrojowym i prawnym oraz podejmując wyzwanie w zakresie systemowego ujęcia sprawiedliwości podatkowej. Akceptujemy przyjęte w doktrynie określenie sprawiedliwości podatkowej, stanowiącej postulat wszelkiego ładu, jako naturalną przesłankę budowy systemów podatkowych ${ }^{24}$. Klasyczne ujęcie sprawiedliwości podatkowej stawia sobie za cel ochronę praw podatnika w danym państwie ${ }^{25}$.

W literaturze przedmiotu powszechna jest prezentacja sprawiedliwości w kontekście zasad prawa podatkowego i opodatkowania ${ }^{26}$. Zasadniczo realizacja

${ }^{22}$ The VAT Reader: What a Federal Consumption Tax Would Mean for America 2011, www.taxanalysts.com/www/freefiles.nsf/Files/VATReader.pdf/\$file/VATReader.pdf (dostęp: 25.05.2012).

${ }^{23}$ Zob. także: G. S. Cooper, The Discrete Charm of the VAT, „Sydney Law School Research Paper" no. 07/65; http://ssrn.com/abstract=1027512 (dostęp: 25.05.2012); M. A. Sullivan, Was the VAT a Money Machine for Europe?, „Tax Notes” 2012, April; http://taxprof.typepad.com/files/ 135tn0143.pdf (dostęp: 25.06.2012).

${ }^{24}$ Zob. więcej: A. Gomułowicz, Idea sprawiedliwości, „Gdańskie Studia Prawnicze” 2007, t. XVI, s. 171-181.

${ }^{25}$ Więcej: A. Gomułowicz, Zasada sprawiedliwości podatkowej, Warszawa 2001.

${ }^{26}$ Pojęciem ,zasady prawa” bardzo często posługuje się zarówno nauka prawa, jak i orzecznictwo. W piśmiennictwie polskim wyróżniane bywają dwa rodzaje zasad. Pierwszy rodzaj wypowiedzi nazywanych ,zasadami prawa” nie ma nic wspólnego z postanowieniami przepisów prawa obowiązującego. Według przedstawianych poglądów zasady te mają wynikać z nigdzie w tekstach prawnych niewyrażonych „założen” czy „zasad ustroju”, z „treści stosunków społecznych” itp. Tak formułowanych „zasad” w ogóle nie można znaleźć wśród postanowień prawa obowiązującego 
wypracowanych dawno temu zasad podatkowych ma na celu gwarancję współistnienia sprawiedliwości podatkowej. Charakter badań, sporów właściwych dla ogólnego pojęcia sprawiedliwości jest identyczny dla sprawiedliwości podatkowej. Odmienne są: używanie pojęć, specyfika używanych pojęć i argumentów. Właściwe dla tych analiz jest także to, iż sprawiedliwość podatkowa stanowi zasadniczo przedmiot badań ekonomistów i prawników ${ }^{27}$.

Podstawą funkcjonowania systemu podatkowego są powszechnie akceptowane wartości. Prawu podatkowemu nie są obce idea sprawiedliwości społecznej oraz zasady państwa demokratycznego. Pojawienie się i rozwój prawa podatkowego stanowi przejaw demokratyzacji społeczeństwa i wiąże się z ideą państwa prawa. Wciąż zmieniające się warunki i okoliczności mają wpływ również na zmianę akceptowanych wartości. Przykładem może być przystąpienie Polski do Unii Europejskiej, co skutkuje obowiązkiem przestrzegania zasady niedyskryminacji podatkowej.

Problematyka zasad podatkowych jest bardzo obszerna, zatem sposób przedstawiania zagadnień dotyczących zasad bywa często odmienny. Charakter opisów zasad podatkowych pozwala wymienić niektóre z ich rodzajów. Są to: zasady klasyczne (np. A. Smith, A. Wagner, D. Ricardo, F. Neumark), podstawowe konstytucyjne zasady podatkowe, zasady podatkowe sformułowane przez Trybunał Konstytucyjny, międzynarodowe zasady podatkowe, zasady dotyczące realizacji praw i wolności podatników (zasady postępowania podatkowego) i zasady opodatkowania podatkami pośrednimi.

Klasyk myśli ekonomicznej, Adam Smith, sformułował cztery zasady podatkowe, które później zostały powszechnie zaakceptowane: zasada równomierności opodatkowania, zasada pewności opodatkowania, zasada dogodności opodatkowania, zasada taniości podatku.

Zasada równomierności (obecnie zwana zasadą sprawiedliwości) jest zgodna z opodatkowaniem proporcjonalnym, tj. podatnicy osiągający różne dochody wpłacają jednakową część swoich dochodów do budżetu państwa. Proporcjonalność opodatkowania odpowiadała istniejącym w czasach Adama Smitha warunkom socjalno-ekonomicznym. Obecnie zasada sprawiedliwości przeszła znaczącą transformację, czego przesłanką były zmiany warunków ekonomicznych,

(zasady, idee). Analizowane „zasady systemu prawa” trafnie i dość zgodnie są w literaturze charakteryzowane tylko jako pewne ,postulaty” natury politycznej lub etycznej, które prawem dopiero mogą się stać, jeżeli zostaną włączone przez ustawodawcę do postanowień prawa obowiązującego. Drugim rodzajem „zasad prawa” mają być „normy prawa pozytywnego” oceniane jako „zasadnicze” (zasady normy). Wyjątkową definicję „zasad prawa” przedstawia R. Dworkin: „zasadą nazywam normę, która ma być przestrzegana nie dlatego, że jej przestrzeganie przybliża lub zapewnia ekonomiczną, polityczną lub społeczną sytuację, która wydaje się godna pożądania, ale dlatego, że tego domaga się sprawiedliwość, uczciwość lub inny aspekt moralności”. Patrz więcej: E. Juchniewicz, Zasady podatkowe, [w:] A. Drwiłło, D. Maśniak (red.), Leksykon prawa finansowego...

${ }_{27}$ Patrz: М. М. Алексеенко, Подоходный налог и условия его применения, Харьков 1885 , c. 6-7. 
politycznych i socjalnych. Obecnie zasada sprawiedliwości jest przedstawiana w świetle dwóch aspektów: sprawiedliwość pozioma i sprawiedliwość pionowa. Sprawiedliwość pozioma polega na tym, że ludzie znajdujący się w podobnej sytuacji i osiągający jednakowy dochód podatkowy powinni płacić podatek według jednakowych stawek podatkowych (koncepcja ability to pay (respective abilities - zdolności płatniczej). Natomiast sprawiedliwość pionowa oznacza, że osoby w różnej sytuacji materialnej powinny płacić podatki, które stanowią różną część ich dochodów podatkowych. Dlatego do wyższych dochodów powinny mieć zastosowanie wyższe stawki podatkowe (koncepcja benefit - korzyści).

Zasada pewności opodatkowania oznacza, że podatek, który powinien zapłacić podatnik, powinien być określony w sposób dokładny. Powinny być w sposób dokładny określone prawa i obowiązki podatników, które są związane z zapłatą podatku. Realizacja tej zasady ma zapobiec dowolności działań organów podatkowych i gwarantować podatnikowi pobór podatku w wysokości wynikającej z przepisów prawa podatkowego, że ,pewność co do tego, ile każda jednostka ma zapłacić, jest, jeśli chodzi o podatki, sprawą tak wielkiej wagi, że nawet bardzo nierównomiernie rozłożone podatki nie są w przybliżeniu złem tak wielkim, jak wielkim złem jest nawet mały stopień niepewności w tym względzie”.

Zasada dogodności opodatkowania wymaga, żeby „każdy podatek był pobierany w takim czasie i w taki sposób, by podatnikowi było jak najdogodniej go zapłacić" (A. Smith). Wygodne i nieuciążliwe sposoby zapłaty podatku powinny zapewnić wpływ na ekonomiczne zachowanie podmiotu. Dogodny termin zapłaty podatku dotyczy sytuacji, w której istnieje największe prawdopodobieństwo, że podatnik ma go czym zapłacić. Zupełnie odmiennie przejawia się realizacja tej zasady w przypadku podatków bezpośrednich i pośrednich. W przypadku podatków bezpośrednich polega na dostosowaniu terminu i sposobu poboru w zależności od źródeł dochodu. Przykładem może być rozróżnienie w tym celu źródeł dochodów z pracy, czynszu nieruchomości, od spadków i darowizn itd. Ma to również wpływ na sposób powstawania zobowiązania podatkowego. Dlatego w poszczególnych konstrukcjach prawo podatkowe ustala bądź samowymiar, bądź wydawanie decyzji podatkowych. Odmienna sytuacja dotyczy podatków pośrednich, które w świetle tej zasady są uznawane za najdogodniejszy sposób opodatkowania. Podatki pośrednie są płacone stopniowo i w małych ilościach. Zmniejszenie ciężaru podatkowego jest uzależnione od prostych zachowań podatnika, tj. od kupowania bądź niekupowania określonych dóbr lub usług.

Zasada taniości (efektywności) opodatkowania oznacza, że koszty poboru podatku były znacznie mniejsze od wpływów podatkowych do budżetu. Głównym postulatem w zakresie danej zasady jest oszczędność opodatkowania. Rozumiemy przez to przede wszystkim ograniczenie wielkości administracji podatkowej. Koszty utrzymania administracji podatkowej mogą pochłonąc wszystkie wpływy podatkowe, więc w rezultacie będzie to już podatek „deficytowy”. 
Do katalogu zasad sformułowanych przez Trybunał Konstytucyjny zalicza się zasadę wyłączności ustawy w kształtowaniu obowiązków podatkowych, zasadę retroaktywności prawa podatkowego, zasadę zaufania do państwa i stanowienia przezeń prawa, zasadę sprawiedliwości, zakaz zmian podatków wymierzanych w skali roku podatkowego, zakaz zmian prawa podatkowego w trybie przewidzianym dla ustawy budżetowej, zasadę zgodności z prawem ${ }^{28}$.

W ujęciu globalnym ujmujemy sprawiedliwość podatkową w znacznie szerszym zakresie. W istocie wychodzimy poza odczucie sprawiedliwości bądź niesprawiedliwości podatników danego kraju, który kształtuje swoją własną politykę podatkową, realizując postulat własnej suwerenności podatkowej. $\mathrm{Na}$ pewnym przykładzie stawiamy sobie zasadnicze pytanie, czy polityka podatkowa Polski powinna mieć na uwadze interesy mieszkańców Kenii i Zimbabwe? Stawiane pytanie wydaje się abstrakcyjne i bardzo odległe. Znane prawu podatkowemu jest pojęcie konkurencji podatkowej pomiędzy krajami. W literaturze przedmiotu konkurencja podatkowa ujmowana jest zasadniczo jako szkodliwa. Zjawisko konkurencji pochodzi od dawno istniejących zachowań podatników, jakimi są unikanie i uchylanie się opodatkowania ${ }^{29}$. Według organizacji OECD, kraje posiadające w swoich systemach podatkowych jedynie nominalne podatki oraz niestosujące podatków zaliczane są do kategorii krajów wprowadzających szkodliwą konkurencję podatkową; często w literaturze określane są jako raje podatkowe ${ }^{30}$. Przykładem braku integralności systemów podatkowych, szeroko rozumianej

${ }^{28}$ Część publikacji poświęcona problematyce zasad podatkowych została opracowana na podstawie: E. Juchniewicz, Zasady podatkowe..., s. 5-14; F. Vanistendael, Legal framework for taxation, [w:] V. Thuronyi (red.), „Tax Law Design and Drafting” 1996, IMF, s. 5-14; www.imf.org/ external/pubs/nft/1998/tlaw/eng/ch2.pdf (dostęp: 25.05.2012).

${ }^{29} \mathrm{Na}$ gruncie polskiego prawa podatkowego przez unikanie podatku rozumiemy wszelkie legalne działania podatnika, które mają na celu zmniejszenie lub eliminowanie obciążenia podatkowego. Cechą charakterystyczną tych działań są całkowicie legalne i akceptowane metody obniżania obciążeń podatkowych. Niedopuszczalne są działania podatnika, które są niezgodne z prawem. Uchylanie się oznacza bezpośrednie łamanie prawa podatkowego, będące często skutkiem czynności in fraudem legis (zmierzających do obejścia ustawy). Podejmowane działania podatnika są nielegalne oraz cechuje je najczęściej oszustwo, wprowadzenie w błąd lub utajenie. Na równi z pojęciem uchylania się często są używane takie pojęcia, jak oszustwa podatkowe oraz omijanie opodatkowania. Pojęcie uchylania się od opodatkowania najczęściej jest przeciwstawiane pojęciu unikania podatków, nadając działaniom w zakresie pierwszego zjawiska podstawową cechę jako działań nielegalnych i karalnych. Zob. więcej: E. Juchniewicz, Unikanie opodatkowania/uchylanie się opodatkowania, [w:] A. Drwiłło, D. Maśniak (red.), Leksykon prawa finansowego...; zob. także: P. Karwat, Obejście prawa podatkowego, Warszawa 2003; С. В. Жестков, Правовые основы налогового планирования, Москва 2002.

${ }^{30}$ Zob. T. Lipowski, Raje podatkowe a unikanie opodatkowania, Warszawa 2004; zob. więcej: More Information on the Harmful Tax practices Work, OECD Centre for Tax Policy and Administration; www.oecd.org/document/49/0,3343,en_2649_33745_33995569_1_1_1_1,00.html (dostęp: 28.05.2012); Harmful Tax Competition: An Emerging Global Issue, OECD Publications, Paris 1998; www.oecd.org/dataoecd/33/1/1904184.pdf (dostęp: 28.05.2012). 
solidarności w zakresie polityk podatkowych (przejawu suwerenności podatkowej krajów członkowskich) może być sytuacja gospodarcza współczesnej Grecji jako państwa członkowskiego Unii Europejskiej. Kraj ten w latach poprzedzających nadejście kryzysu finansowego był atrakcyjnym miejscem prowadzenia działalności gospodarczej oraz przenoszenia siedzib podmiotów gospodarczych z krajów, w których były znacznie wyższe stawki podatkowe podatku dochodowego od osób prawnych. Przykładów można by wskazać wiele, gdyż istotą polityki fiskalnej państw członkowskich UE jest zagwarantowana w traktatach ich suwerenność podatkowa. W istocie mamy brak solidarności podatkowej państw członkowskich UE, które prowadzą własną politykę podatkową. W kontekście Grecji o odczuciu niesprawiedliwości z kolei mówi już nie Grek, a np. polski i niemiecki podatnik, z uwagi na to, że w szczególności działania i polityki podatkowe poszczególnych krajów (np. Grecji) wpływają na sytuację każdego obywatela państw UE. Regionalny przejaw globalnej sprawiedliwości (w granicach UE) przedstawia przykład wykorzystania środków finansowych wypracowanych przez podatników państw UE dla naprawienia gospodarki prowadzącej w szczególności nieracjonalną politykę podatkową, aczkolwiek nadzwyczajnie sprawiedliwą w ujęciu krajowym. Nie możemy przeczyć, że polityka tych krajów (zwłaszcza Grecji) miała za cel dobrobyt mieszkańców danego kraju.

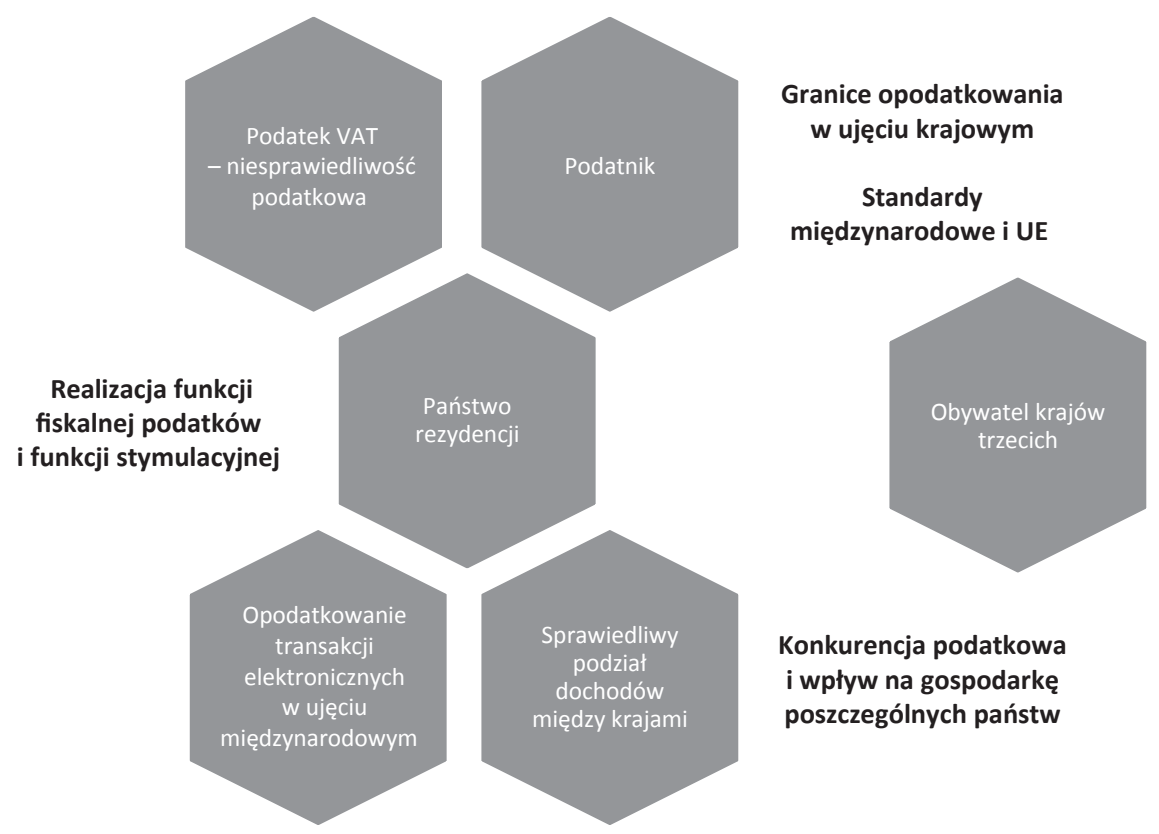

Rysunek 1. Granice globalnej sprawiedliwości podatkowej w międzynarodowym prawie podatkowym

Źródło: opracowanie własne 
Wydana w 2011 r. przez wydawnictwo Springer, licząca ponad tysiąc stron Encyklopedia Globalnej Sprawiedliwości ${ }^{31}$ zawiera bardzo szeroki zakres opisywanych pojęć i opracowań. Instytucję podatków znajdziemy wielokrotnie w zakresie opisów różnych pojęć. Szczególne znaczenie poświęca się podatkowi w kontekście globalnych podatków. G. Brock ${ }^{32}$ przedstawiła możliwości wprowadzania globalnych podatków. Do tej kategorii autorka zaliczyła podatek węglowy, podatek od transakcji walutowych (zwany podatkiem Tobina), podatek od biletów lotniczych, podatek od e-maili, podatek od handlu międzynarodowego oraz podatek od handlu bronią ${ }^{33}$. Jednak zabrakło w tym obszernym opracowaniu systemowej charakterystyki instytucji globalnej sprawiedliwości podatkowej.

\section{Podsumowanie}

Schemat ujęty w niniejszym opracowaniu obrazuje zakres zagadnień dotyczących pojęcia globalnej sprawiedliwości podatkowej w międzynarodowym prawie podatkowym. W pewnym sensie samo pojęcie i zakres badań ma charakter nowatorski. Nie należy pomijać dorobku naukowego poświęconego problematyce ogólnej sprawiedliwości globalnej, który zasadniczo może ujmować wskazówki i kierunki poszczególnych analiz oraz inspirować do stawiania wniosków i tez właściwych międzynarodowemu prawu podatkowemu ${ }^{34}$. Stanowi również punkt odniesienia przy nakreśleniu status quo treści współczesnej rzeczywistości, ściśle dotyczącej zasady globalnej sprawiedliwości podatkowej. Mając na uwadze charakter niniejszej publikacji, można jedynie wymienić poszczególne przeszkody w realizacji postulatów globalnej sprawiedliwości podatkowej. Do kategorii przeszkód można zaliczyć powszechnie występującą w świecie konkurencję podatkową pomiędzy państwami (przejaw globalizacji - mobilność kapitału, konsumentów i pracy), brak międzynarodowej solidarności podatkowej (w tym także w UE), brak należytej współpracy i solidarności państw w międzynarodowym prawie podatkowym oraz niesprawiedliwy podział dochodów pomiędzy krajami (podział dochodów zgodnie z umowami modelowymi dotyczącymi unikania podwójnego

31 Zob. D. K. Chatterjee, Encyclopedia of Global Justice, Salt Lake City 2011.

32 Więcej o G. Brock na stronie internetowej: http://artsfaculty.auckland.ac.nz/staff/?UPI= gbro064\&P=3644 (dostęp: 28.06.2012).

${ }^{33}$ G. Brock, Global taxation, [w:] D. K. Chatterjee, Encyclopedia..., s. 443-445; patrz także: eadem, Tobin tax, [w:] D. K. Chatterjee, Encyclopedia ..., s. 1078.

${ }_{34}$ Zob. zakres globalnej sprawiedliwości podatkowej także w: I. Benshalom, The New Poor at Our Gates: Global Justice Implications for International Trade and Tax Law, „New York University Law Review” 2009, vol. 85; „Northwestern Public Law Research Paper” no. 08-43; http://ssrn.com/ abstract=1319465 (dostęp: 28.05.2012). 
opodatkowania) $)^{35}$. Inny charakter ograniczeń wynika także z braku ambicji organizacji międzynarodowych do podejmowania stosownych działań i braku podatków międzynarodowych ${ }^{36}$. Według koncepcji zasady sprawiedliwości suwerenność podatkową państw należałoby traktować jako przejaw wolności, natomiast wynikającą z tego konkurencję podatkową jako przyczynę wszelkich nierówności w międzynarodowym prawie podatkowym. Międzynarodowy kompromis, przede wszystkim dotyczący zrównoważonego rozwoju świata oraz ochrony wszelkich zasobów naturalnych i środowiskowych, jest już wypracowany. Teraz istotne jest, aby finansowe i spójnościowe polityki międzynarodowe i krajowe zawierały w sobie postanowienia dotyczące globalnej sprawiedliwości podatkowej.

${ }^{35}$ Patrz także: K. Brooks, Global Distributive Justice: The Potential for a Feminist Analysis of International Tax Revenue Allocation, „Canadian Journal of Women and the Law” 2009, vol. 21, no. 2, s. 267-297; http://ssrn.com/abstract=1618779 (dostęp: 28.06.2012); zob. też: I. Benshalom, op. cit. rodowych.

${ }^{36}$ Paradoks międzynarodowego prawa podatkowego, w którym brakuje podatków międzyna- 